\title{
Theological Casuistry and Casuistical Preposterousness: The Fallacious Cases of La pícara Justina
}

\author{
David Mañero Lozano
}

\begin{abstract}
The preliminary pages of La pícara Justina offer a parallel between a purported exemplary reading of Justina's story and court hearings for people accused of crimes, as well as theological views. However, the preposterous circumstances and the arguments used by the female rogue when attempting to exonerate herself, assume such a degree of narrative disproportion and distortion that the discourse moves into parody. Based on these observations, we analyze the function of casuistry within the framework of fictional literature.
\end{abstract}

\section{Keywords}

Casuistry - La pícara Justina - Picaresque novel - Female rogues - Guzmán de Alfarache - Exemplary literature

According to the preliminary pages of La picaraJustina, the novel aims to allow lessons to be derived through examination of the thefts and deceptions perpetrated by its protagonist. To this end, the preface draws a parallel between a purported exemplary reading of Justina's story and court hearings for people accused of crimes, as well as theological views on impious actions. A priori, this declaration of intent - fulfilled through the inclusion of moral summaries at the end of each of the book's sections - is associated with the theological science of casuistry. However, the novel's reader comes up against a number of interpretive challenges. Despite the exemplary approach we are encouraged to take when reading about Justina's life, the preposterous circumstances described and the arguments used by the picara, or female rogue, when attempting to exonerate herself, assume such a degree of narrative disproportion and distortion that the discourse moves into the realm of parody. Moreover, as the novel unfolds there is a gradual confusion of the functions attributable to the voices of the implied author, the narrator, and the marginal notes, which lay out a 
complex dialectic that is difficult to equate with moral didacticism. Based on these textual points of reference and the intertextual relationships between La picara Justina and earlier picaresque novels, this paper aims to analyze the function attributed to casuistry within the framework of fictional literature. It explores, in short, an issue of broad theoretical and historiographical scope with a view toward furthering an understanding of the different conceptions of the novel that developed in Spanish Golden Age literature.

\section{1 \\ Exemplarity and Casuistry: An Interpretive Starting Point}

Few texts in Spanish literature pose as many interpretive challenges as $L a$ picara Justina, a novel from which, ironically, the reader is urged from the outset to draw useful lessons. In fact, even before the book's dedication and preface, the royal license (cum privilegio) at the beginning of the front matter highlights the purported exemplary ambitions of the author. The very first lines, attributed to the royal secretary, claim that said author submitted the book after a great deal of work and study, and describe its edifying function and the presence of "cosas muy curiosas" ("very intriguing content") relating to morality and "buenas costumbres" ("good customs", López de Úbeda 166).

The second of the preliminary texts, the approval, proceeds in the same vein, differentiating between the subject matter, which is on a superficial level, and the work's exemplary intent, which is "encerrada" ("enclosed") on an interpretive level that requires greater effort to comprehend. With respect to the immediately accessible level, allusions are made to the presence of comical stories and "tratos manuales" ("manual dealings") (169), which dictionaries from the era define as illicit communications or business between a man and woman. This definition for the word trato is given in the Diccionario de Autoridades, and its modification by the adjective manual (manual) encourages interpretation of the phrase as a reference to prostitution. As regards the deeper or "enclosed" meaning, the approval mentions the presence of teachings or warnings that are useful for the purpose of avoiding the "engaños que hoy día se usan" ("deceptions practiced these days").

Up to this point, the book's approach is in line with a long tradition dating from medieval times, ${ }^{1}$ although we must suppose it to have been somewhat refined by the influence of Mateo Alemán's Guzmán de Alfarache. It is

1 On the medieval roots of the notion of ejemplaridad ("exemplarity") in Spanish short stories from Disciplina Clericalis to Cervantes and his contemporaries, see González Ramírez, who repeatedly highlights the frequent contradictions between the purportedly exemplary 
common knowledge that this earlier work had brought a renewed, appealingly expressive format to didactic literature by combining consejas, or stories of roguish adventures, with consejos, or moral teachings. It is a well-defined structure with no place for misgivings, as Alemán notes when he advises "no te rías de la conseja y se te pase el consejo" ("don't laugh at the conseja and miss the consejo", 30). His comment makes it clear that the story takes second priority behind the lesson. In Guzmán de Alfarache we also see, as this paper will go on to explore, a new ideological conception wherein archetypical examples of moral conduct are displaced by an interest in evaluating an individual's conduct and conscience in a specific situation or set of circumstances. ${ }^{2}$ These sorts of approaches, undoubtedly prefigured in Lazarillo de Tormes, have been linked to the emergence, or awareness, of subjectivity in the modern novel. According to Maryks, this reflection on an individual's specific circumstances involves "an important shift that characterized the transition from medieval ethics into a modern mentality characterized by a higher degree of subjectivity, responsibility and interiority" (117-18).

This exemplary starting point, which is no doubt within the bounds of the reader's expectations, is immediately endorsed and later explicitly stated by the implied author of La picara Justina, whom it would be more fitting to describe as a literary character rather than the agent or person responsible for the work's ultimate meaning. ${ }^{3}$ Accordingly, in the book's dedication to Rodrigo Calderón, he is compared to a "preciosa abeja" ("precious bee") that knows how to extract "gusto y aprovechamiento" ("enjoyment and utility") from an entertaining read (López de Úbeda 171). However, it is in the preface that the implied author figure deploys all of his rhetorical tools to address the book's aims in detail, a fact that is directly stated in the preface's heading, which reads "En el cual declara el autor el intento de todos los tomos y libros de La pícara Justina" ("Wherein the author states the intention of all of the volumes and books of La picara Justina"). Significantly, the preface begins by endorsing the views of moral theologians who condemn profane books, which are branded as useless and lascivious. The immediate inference is that the author's work falls into a very different category. Indeed, he acknowledges that the subject matter of his novel is the "veneno de cosas profanas" ("poison of profane things"), but to counterbalance this he points to lessons on virtues and disappointments

function declared in paratexts and the plots of the stories themselves, which often undermine the preliminary comments.

2 On the emergence and development of subjectivity in the picaresque novel, see Mañero Lozano (2021).

3 As Dunn points out: “[...] the text of the female narrator is presented by an unidentified and implicitly male commentator" (233). 
"emboscados donde no se piensa" ("which lie in ambush where least expected") (179). This is yet another allusion to the reader who must make an effort to draw hidden teachings out of the text.

The preface also draws on another standard feature of sermon rhetoric: learning life lessons through someone else's experiences. The stated objective is to provide a comprehensive casuistry regarding moral dangers to be avoided. Initially, the book is described as useful for maidens and married women. It is then said to be useful for students, soldiers, apprentices, innkeepers, ministers of justice and, in short, all people of any status, acting in any capacity (184). There is thus a pursuit of totalization reminiscent of the aims of the moral theologians who evaluated cases of conscience, some as exhaustive as Antonino Diana, in Summa Resolutionum Moralium, whose desire to describe a vast number of cases (no less than twenty thousand) led him to include some utterly preposterous situations (cf. Vereecke).

Despite the conventional nature of the arguments set out up to this point, there are also two elements that make the implied author's hermeneutic approach particularly interesting. First, he describes himself as a "testigo" ("witness") to the protagonist's life, and claims that most of her story is true (182-183). After this surprising affirmation, which aims to legitimize an exemplary reading of Justina's thefts and deceptions, the story is compared to court hearings of accused criminals and to moral theologians' views on impious actions. In that sense, the relation between Justina and the implied author could be paralleled to that of a penitent to a confessor.

This interesting parallel, substantiated by Justina's autobiographical account of her story and moral recapitulations inserted at the end of each of the book's sections, would have been associated at the time with the ideological conception and rhetorical practices of casuistry, wherein moral postulates were based on analysis of the specific circumstances of cases of conscience. Remember, there is a fundamental difference between "case" and "example," which Del Río Parra aptly characterized when she noted that

Si bien ambos géneros se encuadran en la didáctica, la casuística atiende a despejar las dudas que presentan diversos casos prácticos (reales o posibles [...]). Mientras que el ejemplo considera una situación para concebir un principio abstracto, el caso se centra en lo particular dudoso, donde reside una gran dificultad moral para resolver esta última con éxito

Although both are encompassed within didactics, casuistry seeks to dispel doubts presented by different (real or possible case studies [...]). While the example considers a situation in order to formulate an abstract 
principle, the case focuses on the specific area of doubt, wherein lies a great moral challenge that must be resolved.

DEL RÍO PARRA 14

It is also worth noting that the case involves a "tension [...] between norms and exceptions. They need each other; they fuel each other" (Ginzburg xii). Compilations of case comparisons called collationes casuum proliferated during the Spanish Golden Age, particularly by Jesuit authors (Fernández Cano 493), and they had an appreciable influence on both the dramatic genre (Sullivan, Álvarez, Kallendorf and Gómez Canseco) and the prose of the time (Tierno Galván and Sánchez Jiménez). ${ }^{4}$

It should be remembered, on the other hand, that some critics view Mateo Alemán's Guzmán de Alfarache, the primary picaresque reference for La pícara Justina, as a work of a "consumado casuista" ("consummate casuistry"), in which "los predicados morales dependen del contexto" ("moral predicates are dependent on context") (Darnis 123, 124). Several crucial passages in Alemán's work could perhaps lend themselves to this conclusion. With respect to Guzmán's act, at the end of the book, of turning in a fellow sailor who plans to mutiny and seize control of the royal galley, Cavillac believes that it "se inscribe en la moral casuística" ("falls within the framework of casuistical morality", 122). Furthermore, the behavior of the picaro in said work, which Cavillac (161) likens to Alemán's own ideology, is consistent with both Machiavellian principles and Jesuit recommendations on this specific case. Similarly, the denouement of the novel Bonifacio y Dorotea contained within Guzmán, in which Dorotea decides to preserve her conjugal honor by hiding her rape at the hands of Claudio, is also in line with the conduct advocated by casuists to prevent an even greater ill (Cavillac 138). Other experts, such as Gómez Canseco (Alemán 2012: 59, n. 103), interpret some passages as critical of casuistry. Scholars are not, therefore, in complete agreement regarding Alemán's commitment to this mindset. In my view, which will be further developed in this paper, La picara Justina as a response to Guzmán de Alfarache necessarily entails a casuistical interpretation of Alemán's novel.

In sum, the preface of La pícara Justina conveys the idea that the writer has set himself an ambitious task of moral reformation which, inevitably, engages in an intertextual dialogue with Alemán's Guzmán de Alfarache and with its aim of "fabricar un hombre perfecto" ("creating the perfect man") (Alemán

4 For a clear, concise review of the evolution of casuistry and its influence on Spanish Golden Age literature, see Sánchez Jiménez (2014: 83-89). See also an early study by Caro Baroja. 
2014: 463). In this same preface, the implied author acknowledges that reading Guzmán led him to broaden the scope of his original plan. It remains unknown, however, to what degree he aims to reproduce the same rhetorical approach, nor do we know the extent of his admiration for this literary model. Following this clear explanation of its aim and significance, the book proceeds to Justina's autobiographical account. Nevertheless, contrary to the expectations created in the preliminary pages, the reader encounters a number of challenges with respect to extracting moral canons from the autobiographical incidents described, which go far beyond the types of interpretive exercises typically found in works intended for educational purposes. In this regard, it seems fitting to highlight a number of different circumstances, each of which will be addressed in its own respective section of this essay. All of them relate in some way to the elements involved in theological study of cases of conscience.

\section{Irrelevant Circumstances and Interpretations}

Although the preface urges the reader to interpret Justina's life in an exemplary light, most passages focus on inane events that are irrelevant for the purpose of exemplarity or for furthering the autobiographical account. We will also see that the preposterous life circumstances of the cases described claim such a disproportionate share of the narrative that they shift the discourse into the realm of parody. One example is found at the beginning of Justina's autobiography. The first topic addressed by our protagonist/narrator, with respect to which the picara adopts a descriptive and interpretive role, is highly frivolous. It revolves around a hair that has accidentally become stuck to the quill that Justina is using to write her memoirs. The irrelevance of the situation takes the aim of describing the protagonist's life circumstances to a ridiculous extreme, in what could be interpreted as a parody of the importance given by casuists to describing the minutiae of the cases they study. A prime example is the set of inquiries suggested in the Breue Compendio de Confessión, regarding "cuál, cuándo, por qué, en qué lugar, en qué tiempo, con qué instrumentos, por quién o contra quién pecamos y en qué, por cuánto, la cantidad del pecado o daño que se hace, si fuere poco o mucho, notable o no notable" ("what, when, why, where, at what moment, with what instruments, for whom or against whom we sin and in what way, to what extent, whether the degree of sin or damage done is small or large, noteworthy or unremarkable") (López de Alvarado 3). ${ }^{5}$

5 On confession manuals and treatises, see González Polvillo (253), who mentions another edition of López de Alvarado's work published in Rome in $155^{8}$. 
Thereafter, Justina lays out a complex set of scholarly examples for illustrative purposes. This interpretive exercise is also approached in a parodic fashion, given that it aims to shed light on an altogether banal occurrence. To this end, Justina draws a symbolic, presumably invented parallel between inconstant friendship and a duck, the animal from which her writing quill originated. Next, she begins a humorous tale of how Queen Isabel I uses a play on words to give King Fernando to understand that monarchs' secrets are impossible to conceal. She adds in two scholarly references. The first is classical in origin and describes Jupiter in the company of the celestial bodies, as evidence that the god is always visible. The second references the king's standard, envisioning it laden with the eyes of his subjects, as an example of the fact that monarchs' actions are always judged. From all of this, Justina deduces that she feels honored because although she is not royalty, her flaws and mistakes are made known by the hair in question. Justina herself ridicules the moral dimension ascribed to the banal situations she is involved in. Consider, for example, the passage in which her cousin reprimands her for making noise with some castanets briefly and almost unconsciously (433). The picara compares his overreaction to the details required in Inquisition cases to judge the severity of an offence. Passages such as this highlight the trivial events that make up Justina's autobiography and call into question the relevance of the exemplary function attributed to them in the preface. Such a critique of casuistry's concern with minutiae, even deploying them as a facile justification of questionable behavior, would later be expressed most famously in Blaise Pascal's judgement against the Jesuit "laxism" (Lettres provinciales 1657). Suffice the examples given thus far to give an idea of the exaggerated nature of the rhetorical process, evident in both the excessive number of examples cited and the grandiosity of the gods and monarchs used as a basis for comparison. ${ }^{6}$

From a hermeneutical perspective, there also is another important point. According to the preface, by making a special interpretive effort the reader should be able to discern the moral teachings concealed on the book's hidden level. On this level, however, the only thing the reader can make out is a complex jumble of erotic symbols. ${ }^{7}$

6 As Oltra (66) points out, this sharp contrast between the quality of the examples or points of comparison and the trifling purpose for which she uses them is one of the most characteristic rhetorical processes in the book's organizational structure.

7 One example is the erotic reading made by Garrote Bernal (224-225), who interprets as sexual references the terms tratar (have dealings with), pluma (quill) and pelo (hair) used in the passage in question. See also Dunn $\left(235^{-236)}\right.$. The same sort of reading has been made of other passages. Márquez Villanueva's work is a good example of this. 
The chapter devoted to the hair on the quill also contains an interesting rhetorical exercise consistent with casuistical practices. After spending several pages describing the trifling matter of the hair on the quill, Justina, who decides to address said quill as a silent conversational partner, admits the truth of the accusations of syphilis that the hair has supposedly thrown at her. Unexpectedly, and without enlightening the reader as to the relevant background events, she thus offers up information of key importance in her autobiography.

The interesting twist in this case is the way that Justina then attempts to dispel any guilt by presenting various mitigating circumstances to "señora pluma" ("Mrs. Quill"), who in a sense takes on an accusatory role. From this point on, the picara begins to express herself as if she were on trial, beginning her statements with the formula "Confieso ..." ("I confess ..."). In fact, the first thing she does is confess her culpability with respect to the accusations. However, the exaggerated number of formulas and plays on words she uses to paraphrase the fact that she has the disease progressively undermines the rhetorical effectiveness of the act of confession. Her statements thus cease to be interpreted as a gesture of humility or admission of guilt, and come to be construed as a display of literary conceptism that showcases the narrator's boastful character. Her rant ends with the following statement: "Concedo que soy pelona docientas docenas de veces" ("I concede that I am bald two hundred dozen times over", 207).

Justina then attempts to play down the importance of the disease, describing it as a very common illness, which to some extent dilutes her own culpability. Even so, once again this strategy of guilt avoidance loses its effectiveness by becoming a pretext to introduce a string of witty puns. The imagery employed, which would have had some degree of argumentative efficacy had it been used within reasonable bounds, becomes progressively ludicrous. Eight rhetorical questions are posed in total, one after another, to the point where the redundancy and the ridiculous formulations employed render the device wholly useless.

The next of the extenuating circumstances outlined by the picara is the fact that her confession, made voluntarily, if not vaingloriously, could prevent others from falling ill, with the inference that she is performing a good deed. To make this point, Justina embarks on a long declaration in which she insists that she has no reason to be ashamed of her illness, or of having gone bald because of it. To strengthen the weight of her argument, she illustrates her fortitude in the face of her illness and baldness by means of a fable. She tells of the frog, said to have once had hair, who was jealous of the swan's song and the fly's 
peaceful sleep in the winter, and asked Jupiter for both abilities. In exchange for the loss of the frog's hair, the god gave it a pillow and a hairy tongue so it could sleep and sing like the animals it envied. If the fable itself is nonsensical, the way it is applied is even more so. Justina concludes that it shows that while healthy people are at mass listening to sermons, those with syphilis stay asleep. She also uses it as proof that those with syphilis have the gift of gab, like the frog after it was granted its new tongue.

She wraps up her arguments by claiming that she is, figuratively speaking, akin to a preacher who stands at the hangman's noose, and affirms that she can only be condemned by unspiritual people who refuse to see an example in her case (214). This is, therefore, an example that merits consideration within the framework of theological casuistry. Nevertheless, despite the extenuating circumstances which Justina believes make her case an example of virtue, the arguments she sets out are plainly ludicrous and lacking in logic and rationality. ${ }^{8}$

This same rhetorical process is used in other passages of the work, enabling the reader to perceive easily the automated, ineffective mechanisms Justina employs to construct exculpatory discourses. One example is the last of the "books" that make up the work, in which the picara describes inheritance issues and money-related lawsuits with her relatives. The first thing she sets out to do is discredit the other party, represented by her siblings. She thus brands them as "crueles enemigos" ("cruel enemies", 842) and describes her sisters as "adversarias" ("adversaries", 843). According to Justina, the other women's dislike for her is rooted in the same instinct that makes a bully attack those who stand out for their intelligence. After these reflections, to illustrate the crux of her argument she draws on her usual barrage of examples, which are once again applied with an absurd logic that undermines their argumentative efficacy. To corroborate the supposed parallel to Justina's relationship with her siblings, she recounts the familiar tale of the elephant harassed by mice. According to the picara, the mouse chases the elephant due to the aversion that a creature supposedly born of corruption, the mouse, has for a creature distinguished by a tendency to fall in love and procreate. Once again, the arguments she lays out are humorous and lacking any logical basis, which invalidates the rhetorical strategy she uses to defend herself against the accusations.

In sum, everything seems to indicate that the ultimate aim is to use Justina's character to deride the formulation of complex, contrived rhetorical arguments, which are employed to substantiate potentially extenuating circumstances for

8 As, in other context, Dunn explains: "Narrative logic is suppressed [...]. The consistency of the scene depends solely on Justina's aesthetic of verbalized comic surprise” (240). 
the acts of which Justina has been accused. In my view, in the passages cited above the primary parodic targets are the argumentative procedures used to justify conduct that would be classed, a priori, as reprehensible according to the moral stance adopted in the preface. In addition to the examples given, there are two passages in La pícara Justina which Gómez Canseco (168) points to as burlesque examples of casuistical justification of theft and usury, respectively: "Señor talego, digo teólogo, no niego que burlas con la bolsa traen consigo carga de restitución. Bien sé que es gran pecado, pero [...] no hay pecado más escusable que aquel que procede de la necesidad de comida y sustento" ("Mr. Talego [literally, 'corpulent person' and also 'sack', used mockingly here due to its similarity to teólogo (theologian)], I mean theologian, I don't deny that tricks of the purse bring with them a duty of restitution. Well I know it is a great $\sin$, but $[\ldots]$ no sin is more forgivable than one rooted in the need for food and sustenance", López de Úbeda 783-784); and

[...] es como caso de conciencia en materia de restitución puesto por boca del mismo mercader interesado, que lo afeita de manera que, si encuentra un nuevo teólogo [...], no solo le tumbará, pero harale parecer que un promontorio de injusticia es monte de piedad, y una manifiesta usura es una variedad heroica

it's like a case of conscience on the subject of restitution that is placed in the mouth of the very merchant it concerns, who embellishes in such a way that if he finds a new theologian [...], he will not only defeat him but also make a hill of injustice seem like a mountain of piety, and manifest usury a type of heroism. $(864-865)^{9}$

Let us consider one of the short stories narrated by Justina, who tries to illustrate how those who write about their own lives can fall prey to misrepresentation. It is about a humble tailor who manages to amass a fortune and decides to change his surname to Pimentel, to appear to be of higher social standing. He also orders a carved stone coat of arms depicting scallop shells, the Pimentel family emblem, to hang on the door of his home. The case is brought to the authorities and the tailor is ordered to either remove the coat of arms or appear before the judge to declare why he appropriated the Pimentel insignia. He gives three reasons, each more absurd than the last. First, he argues that

9 For an interpretation of this passage in its sociocultural context, see Del Río Parra (128). 
the stonemason simply did the job that the tailor commissioned him to do. Second, he contends that he incurred financial costs in order to produce the coat of arms. Finally, he argues that his decision to include the shells was a tribute to the many shells he carried back in his hat from pilgrimages made to Santiago de Compostela, because the charity he received on the pilgrimages made him rich. With respect to the last argument, he notes that it would be heresy to oppose an act performed out of devotion, for which reason the judge, who is a "cristiano temeroso" ("God-fearing Christian", 315), decides to exonerate him, and the tailor receives legal permission to impersonate the Pimentels.

The tale is a ridiculous and, in my view, conscious application of casuistry, which uses the "doctrine of mental reservation" to legitimize the telling of halftruths when the declarant's background situation is complicated, as Somerville shows. Mateo Alemán himself explicitly legitimizes opportune silencing of the truth, which he justifies by means of an allegory. The first part of Guzmán de Alfarache tells of how The Truth, after being taught a lesson by the harm resulting from uncovering falsehoods, decided to pretend to be mute to avoid future injury (Alemán 2014: 317-320). ${ }^{10}$

Both the tailor's arguments and the judge's verdict have a clearly parodic dimension, as does the fact that Justina uses this example to justify the stance she takes when narrating her life. She clarifies that the tale has been included in reference to the inclination toward falsifying facts that supposedly befalls those who write their own memoirs. However, after recounting the tale, in which the lying tailor emerges victorious by appealing to the sort of arguments that characterize casuistry, Justina identifies with his fraud and comments that both of them are, figuratively speaking, from the same province of Picardia ("Cunning"), that is, that they make a show of their deceptions whenever possible.

The narrative fallacy that Justina boasts of in this passage is a practice seen repeatedly throughout the work, which she employs when recounting her own experiences as well as in biographical descriptions of her ancestors. In the style of the most representative picaresque novels, Justina summarizes the lives of her parents. In a clearly parodic application that exaggerates the genre's characteristic features, however, she also includes an entire litany of biographies of her grandparents and great-grandparents, which serve an essentially comedic purpose.

Employing the same sort of procedure as that used by the fraudulent tailor, she describes as virtuous qualities certain flaws that could be pointed to in her ancestors. Her mother, for example, she describes as compassionate to

10 For a study of lies in the picaresque novel, see Dueñas, who draws a connection between this passage from Guzmán de Alfarache and casuistry (109). 
the poor, a conclusion justified by Justina's memories of how she forbade poor people to enter her inn with the alleged intention of preventing the suffering of those who didn't have enough money to cover their expenses (376). With respect to her father, after listing a vast number of strategies (most of them fraudulent) which he used to gain the highest possible profit from customers at the inn, Justina identifies his most prominent traits as discretion, erudition and masterful skill (371). In a sense, the father does possess these qualities, but Justina ignores the fact that these three traits are typically used with virtuous intent rather than for personal gain.

On this point, I would be remiss not to mention Guzmán de Alfarache's casuistical defense of the thefts committed by his father. With the aim of justifying them, he argues that although his father stole other people's property several times, he himself was also a victim of robbery. Guzmán also adds - broadening the scope of his reasoning to encompass all merchants in general - that only confessors have the right to hear the facts, and only God the right to judge their guilt (Alemán 2014: 50).

The narrative strategy of dressing up flaws as virtues, which could be viewed as a burlesque replica of casuistical practices, is not exclusive to La picara Justina. Among the many parallels between this work and Quevedo's El Buscón are several passages that employ very similar procedures. ${ }^{11}$ Another prime example is a passage from the famous liberation of the galley slaves by the character Don Quijote, who uses indirect language to interpret the crimes that have been reported to him in a positive light, relegating to a secondary position the true reasons that the prisoners were sentenced. ${ }^{22}$ As Close points out, Don Quijote's act of taking justice into his own hands and setting the delinquents free is based on "a world-upside-down view of the relation of prisoners to the

11 The protagonist's father, Clemente Pablo, is described as a person "de buena cepa" ("from good stock"), that is, noble. We also see, however, a playful ambiguity arising from the word cepa, which also means "grapevine", in an allusion to his excessive taste for alcohol (Quevedo 55). Similarly, when introducing Aldonza de San Pedro, the picaro's mother, the fact that she has few enemies is highlighted as a positive trait, but immediately afterwards it is mockingly noted that not even "los tres del alma" ("the three of the soul", $5^{6}$ ) number among them, that is, the world, the devil and the flesh. Along the same lines, the expression "persona de valor" ("person of value") conceals a malicious reference to her status as a woman who can be bought for a sum, or a prostitute. Furthermore, it is said that Pablos de Segovia's brother "robaba a todos las voluntades" ("stole everyone's hearts", 56), a description that ironically praises his affable nature while alluding to his skill as a thief even at the tender age of seven years old.

12 Here, and in other examples that draw on criminals' slang, those who steal other people's property are classed as lovers, and those who confess their crimes as songbirds, or singers (Cervantes 259-260). 
law underpinned by a casuistical pun" (15). Incidentally, the galley slave who features most prominently in the tale, Ginés de Pasamonte, could be considered a burlesque of Guzmán de Alfarache's character. This, in turn, could be interpreted as Cervantes' response to the casuistry that some might ascribe to Alemán's work. ${ }^{13}$

\section{$5 \quad$ Nullification of the Implied Author's Perspective}

As we have seen, despite the apparent soundness and schematism of the explanations provided in the preface, a number of issues arise when reading the work which progressively undermine the relevance and authority of the implied author's initial statements. It should also be noted that the implied author's voice, which we hear throughout the work by means of observations made at the end of each chapter, does not always focus on Justina's actions. The comments at the end of the chapters about a group of students called "La Bigornia" ("The Anvil"), for example, only censure the conduct of said group, which kidnaps Justina. There is no censure of Justina, who rejects her abductors from start to finish and emerges victorious from her dangerous encounter with them. These chapters thus leave the reader with an impression of the character's pre-eminence with respect to the implied author's voice, whose significance pales in comparison to the prominence attained by Justina in terms both of the action and of passing judgment on the deplorable conduct of her abductors.

Another notable example appears in Chapter 3 of Book III, entitled "De la vieja morisca" ("The Old Moorish Woman"), in which the implied author's final comment adopts a stance similar to the critical tone used by Justina

13 With respect to another prisoner who appears in this tale, accused of maintaining incestuous relations, Redondo (242-244) points to a possible Cervantine parody of casuistical cases of conscience on the subject of incest. For his part, Gómez Canseco (168, n. 5) observes a clear burlesque allusion to casuistry in Don Quijote, when the barber, Master Nicholas, uses the following words in an attempt to allay Sancho's fears that his master may wish to enter the clergy: "[...] rogaremos a vuestro amo, y se lo aconsejaremos y aun se lo pondremos en caso de conciencia, que sea emperador y no arzobispo" (“[...]we will entreat your master, and we will advise him, even putting it to him as a case of conscience, that he should become an emperor and not an archbishop.") (Cervantes 325-326). See also Michael Scham's work in this volume. On a related note, Gómez Canseco argues that Cervantes devised the plot of La Gran Sultana within the framework of casuistry. Further relevant observations are made by Sáez (6) regarding the play Pedro de Urdemalas. 
to describe the Moorish witch. Consequently, the differences between the character's perspective and that of the author largely disappear.

In some cases, Justina's character takes over the role of the implied author's voice in guiding readers to interpret the work correctly, as in the passage where she notes that "lo bueno se tome por veras, y lo que no fuere tal, pase en donaire, porque lo contrario sería sacar de las flores veneno" ("the good must be taken for truth and what is not good as a joke, as to do otherwise would be to draw poison from flowers", 736). The functionality of these sorts of observations is undermined by placing them in the mouth of a narrator who lacks credibility. The functions attributable to the implied author's voice are therefore nullified by the overwhelming presence of Justina, a manifestly deceitful character. As Friedman notes, "[w]hile the author has the last word in each section, Justina has the major voice" (88).

Even more interpretive difficulties arise if we consider the confusion caused by the division of the functions attributable to the narrative voices of the author and the protagonist, which aren't always easily reconciled with the explanations given in the preface. In this respect, it should be noted that the implied author's comment at the end of Chapter 4 of Book IV doesn't address the specific circumstances of said chapter:

Una mujer libre a la misma Iglesia santa pierde el respeto y en ella se descompone, porque quien niega a Dios la posada de su alma y la tiene tan en poco que, de casa de Dios, la hace de demonios, tampoco atiende cuán digno es de suma reverencia aquel divino templo en que Dios está real y verdaderamente

An unconstrained woman has no respect even for the Holy Church, and inside it she loses her composure, because those who deny God lodging in their soul and hold it in such little regard that from the house of God, they turn it into a sty for demons, are also unable to see how worthy of utmost reverence is that divine temple wherein God really and truly resides. $(956)$

Indeed, the shifting of the events narrated in this chapter to the wholly theological sphere involves such reductionism that the scope of its application is almost marginal. In any event, the comment seems to have been written independently from the development of the plot, and to limit itself to highlighting a point that is nothing more than anecdotal in the context of the chapter and the work in general. 
It is also worth noting that some of the work's marginal notes distance themselves from the implied author's voice. One example is the one that tells us that the author is angry at the character of the old Moorish woman and is thus making a pretense of his reluctance to write in verse the summary preceding the chapter about her (869). We are thus led to infer the existence of a different narrative level superior to that of the implied author, which increases the complexity of interpreting the text and relativizes the exemplary aspirations stated in the preface. Other notes, moreover, refer to passages from Justina's autobiography. One example is found in the chapter of her account that contains the following marginal comment: "A propósito de la mancha de la saya, prosigue artificiosamente el autor la introducción de su libro" ("In relation to the stained tunic, the author skillfully continues the introduction to his book", 223). Later on, also in relation to Justina's remarks on the book's intent, we find these two notes: "Intento del autor en su libro. Es desengañar ignorantes" ("Intention of the author in his book. Is to enlighten the ignorant", 253). We see, then, that this superior narrative level, which peeks out from the marginal notes, refers to the voices of the protagonist and the author as a single entity, serving to undermine the privileged role adopted by the implied author's voice in the preface.

\section{Purpose of the Casuistical Approach and the Originality of La pícara Justina}

The casuistical approach used in La picara Justina, which is executed in an exaggerated fashion lacking in functionality, could be interpreted as a means of taking Alemán's depiction of moral reform based on the life of a rogue to its very limits, with a clearly parodic intent. In my view, the aim is not to negate the value of exemplary literature. The work calls into question the use of the humble figure of the rogue as a means of conveying moral teachings. Underpinning the ludicrous and merciless parodic development of La picara Justina is a criticism of Alemán's break with the conventions of literary decorum which, just as Lope did with respect to comedias, initiated a complete renewal of literary conventions (Mañero Lozano 2009 and 2017, on the respective authors).

At the opposite pole, La picara Justina is a reaction to Alemán's narrative innovations. The contributions of the work are not, however, restricted to the moral level that underpins its rejection of Alemán's formula. As in Don Quijote, which manages to create a universe independent from books that parody chivalry, La pícara Justina transcends mere parody and offers an extremely original 
pursuit of a pure class of fiction that is also independent of treatises on moral theology. Among other innovations, it creates multiple narrative voices with their own identities which claim an independent space within the fictional work, serving to drive forward a process of literary experimentation unconstrained by moral didacticism.

\section{Acknowledgements}

This study is part of the Spanish Ministry of Science, Research and Universities' R\&D Excellence Project (reference: FFI2017-82344-P), funded by the Spanish National Research Agency (AEI) and the European Regional Development Fund (EDRF). It is also one of the activities funded by the HUM-78o Research Framework ("Hispanic Literature Studies of the University of Jaén"). I would like to thank Marlen Bidwell-Steiner, Michael Scham and David González Ramírez for their constructive observations regarding this paper.

\section{Works Cited}

Alemán, Mateo. Guzmán de Alfarache. Ed. Luis Gómez Canseco. Madrid: Real Academia Española (Biblioteca Clásica, 42), 2012.

Alemán, Mateo. Guzmán de Alfarache Iy II. Ed. David Mañero Lozano. Obra completa, 3 vols. Eds. Pedro M. Piñero Ramírez and Katharina Niemeyer. Madrid-Frankfurt am Main: Iberoamericana/Vervuert - Junta de Andalucía - Universidad de Sevilla, 2014.

Álvarez, Miguel. El probabilismo y el teatro español del siglo XVII. Unpublished doctoral thesis. New York: New York University, 1982.

Caro Baroja, Julio. “Probabilidades, laxitudes y corrupciones.” Las formas complejas de la vida religiosa: Religión, sociedad y carácter en la España de los siglos XVI y XVII. Madrid: Akal, 1978: 517-55o.

Cavillac, Michel. "Guzmán de Alfarache" y la novela moderna. Madrid: Casa de Velázquez, 2010.

Cervantes, Miguel de. Don Quijote de la Mancha. Ed. Francisco Rico, in collaboration with Joaquín Forradellas. Barcelona: Círculo de lectores/Centro para la Edición de los Clásicos Españoles, 2004.

Close, Anthony. "The Liberation of the Galley Slaves." Cervantes 27.1 (2007): 12-30.

Darnis, Pierre. "Guzmán de Alfarache, la paradoja del mentiroso y los mundos posibles del lector." eHumanista 34 (2016): 105-133. 
Del Río Parra, Elena. Cartografías de conciencia española en la Edad de Oro. Mexico: Fondo de Cultura Económica, 2008.

Dueñas, Rafael Antonio. De pícaros y mentirosos en la novela picaresca española del Siglo de Oro. Doctoral Dissertation. Stony Brook University, 2014.

Dunn, N. Peter. “Rogue Females.” Spanish Picaresque Fiction. A New Literary History. Nueva York: Cornell University Press, 1993: 232-251.

Fernández Cano, Antonio. "La casuística: un ensayo histórico-metodológico en busca de los antecedentes del estudio de caso." Arbor 171.675 (2002): 489-511.

Friedman, Edward H. "The Voiceless Narrator: the Spanish Feminine Picaresque and Unliberated Discourse." The Antiheroine's Voice: Narrative Discourse and Transformations of the Picaresque. Columbia: University of Missouri Press, 1987: 69-118.

Garrote Bernal, Gaspar. "A pelo y a pluma: algoritmos de conceptos en Castillejo y 'La Pícara Justina.' (Con una digresión para uso de cervantistas)". Cervantes y su tiempo. Eds. Juan Matas Caballero and Balcells Domench, Jose María. Coord. Desirée Pérez Fernández. León: Universidad de León, Secretariado de Publicaciones, 2008: 207-232.

Ginzburg, Carlo. "Preface." A Historical Approach to Casuistry. Norms and Exceptions in a Comparative Perspective. Eds. Carlo Ginzburg and Lucio Biasiori. London/New York: Bloomsbury, 2019: xi-xx.

Gómez Canseco, Luis. "Probabilismo en Cervantes: La gran sultana como caso de conciencia." Criticón 109 (2010): 167-186.

González Polvillo, Antonio. Análisis y repertorio de los tratados y manuales para la confesión en el mundo hispánico (ss. XV-XVIII). Huelva: Universidad de Huelva, 2016.

González Ramírez, David. "La novela corta del Siglo de Oro en tela de juicio: la ejemplaridad y su función retórica (a propósito de la tradición medieval, los novellieri y las Novelas ejemplares de Cervantes)." eHumanista/Cervantes 6 (2017): 56-92.

Kallendorf, Hilaire. Conscience on Stage. The Comedia as Casuistry in Early Modern Spain. Toronto: University of Toronto Press, 2007.

López de Alvarado, Garci. Breue compendio de confessión. diuidido en quatro capítulos. a honrra de dios y vtilidad de todo fiel christiano. Venice: Giouanmaria Bonelli, $155^{2}$. López de Úbeda, Francisco. Libro de entretenimiento de la pícara Justina. Ed. David Mañero Lozano. Madrid: Cátedra (Letras Hispánicas, 707), 2012.

Mañero Lozano, David. "Del concepto de decoro a la «teoría de los estilos»: consideraciones sobre la formación de un tópico clásico y su pervivencia en la literatura española del Siglo de Oro." Bulletin Hispanique 111.2 (2009): 357-385.

Mañero Lozano, David. "Tragicomedy and Literary Decorum: Theoretical Foundations of the «Third Dramatic Genre» in the Origins of Spanish Theater." Iberoromania 86 (2017): 151-172. 
Mañero Lozano, David. "Los sueños de Proteo. De Lázaro de Tormes al Pijoaparte de Marsé." Estudios culturales y literarios del mundo hispánico. Madrid: CSIC, 2021.

Márquez Villanueva, Francisco. "La quinta langosta de La pícara Justina." Boletín de la Real Academia Española 79 (1999), 278: 355-376.

Maryks, Robert A. Saint Cicero and the Jesuits: The Influence of the Liberal Arts on the Adoption of Moral Probabilism (Catholic Christendom, 1300-1700). Aldershot: Ashgate, 2008.

Oltra Tomás, José Miguel. "La casuística estructural en La Pícara Justina, de Francisco López de Úbeda." Estudios Humanísticos 5 (1983): 55-67.

Quevedo, Francisco de. La vida del buscón. Ed. Fernando Cabo Aseguinolaza. Barcelona: Crítica (Biblioteca Clásica, 63), 1993.

Redondo, Augustin. "Los amores burlescos en el Quijote." Cervantes 27.1(2007):227-248. Sáez, Adrián J. "Elementos religiosos en Pedro de Urdemalas." e-Spania 18: 1-11.

Sánchez Jiménez, Antonio. "Los casos de conciencia en la novela pastoril del Siglo de Oro: casuismo y probabilismo en la Arcadia (1598) de Lope de Vega." Revista de literatura 76.151 (2014): 79-100.

Sommerville, Johann P. "The «new art of lying»: equivocation, mental reservation and casuistry." Conscience and Casuistry in Early Modern Europe. Ed. Edmund Leites. Cambridge: Cambridge University Press, 1988: 159-184.

Sullivan, Henry W. "Moral Probabilism and Casuistry in Spain during the Counter Reformation." Tirso de Molina and The Drama of the Counter Reformation. Amsterdam: Rodopi, 1976: 40-51.

Tierno Galván, Enrique. “Introducción.” Baltasar Gracián, El político. Ed. Evaristo Correa Calderón. Salamanca/Madrid: Ediciones Anaya, 1961: 4-14.

Vereecke, Louis-Gustave. "Casuistique." Encyclopcedia Universalis, 2019. Web. July 25 202O. URL: http://www.universalis.fr/encyclopedie/casuistique/. 